\title{
The Influence of Consumer Behavior, Competitive Advantages on the Performance of MSMEs during Covid-19
}

\author{
Siti Nurmaliki ${ }^{\mathrm{a}}$, Setyo Riyanto ${ }^{\mathrm{b}}$ \\ Master of Management Student, Mercu Buana University, Jakarta, Indonesia \\ Associate Professor, Mercu Buana University, Jakarta, Indonesia
}

\begin{abstract}
The study aimed to demonstrate changes in consumer behaviour, a competitive advantage over the performance of businesses, micro, small and medium enterprises (MSMEs) in the middle of the pandemic Covid-19. This study was conducted by spreading the questionnaire to 110 respondents. This research uses descriptive methods and quantitative approaches to see the influence between consumer behaviour, a competitive advantage over MSME performance. Data is processed using multiple linear regression analysis methods using the SPSS 16.0 application.
\end{abstract}

The results showed that consumer behaviour, competitive advantage significantly impacted SME's performance in the middle pandemic Covid-19.

Keywords:- Competitive Advantage, Consumer Behaviour, Covid-19, MSME Performance

\section{INTRODUCTION}

The Coronavirus outbreak has stolen the attention of all citizens of the world. The World Health Organization (WHO) even officially announces the Covid-19 as a global pandemic or plague. Coronaviruses are thought to impede business processes because the work that is usually done in front of the face is difficult to do.

Consumer behaviour around the world suddenly changed since the onset of the Coronavirus pandemic or Covid-19. This sudden change made many entrepreneurs confusion. Some businesses have an unexpected advantage, but others have suffered a lot of harm. Because nobody knows when a pandemic will end and the long term effects it generates.

The main challenge of today's business strategy is finding ways to achieve a sustainable competitive edge compared to other products and companies competing in the market.

The existence of micro small and medium enterprises (MSMEs) which is the largest part of the national economy, is an indicator of the participation rate of people in various sectors of economic activity. SMEs have been proven to be reliable as safety valves in times of crisis, through the mechanism of creation of employment opportunities and added value. This strategic role and function can be enhanced by playing MSME as one of the complementary business actors to the development of the national economy, and not the subordinary of other business actors. Success in improving MSME means strengthening.

Community's economic business. This will help accelerate the process of restoring the national economy, as well as a real source of support for local governments in implementing government autonomy (Budi: 2006).

MSMEs is a potential business that is highly encouraged by Governments; Because of more and more entrepreneurial society than the better and the economy of an area because of local resources, local workers, and financing.

\section{> Be absorbed and optimally beneficial.}

Although SMEs have some advantages that allow SMEs to thrive and persist in crisis, some facts also show that not all small businesses can withstand the economic crisis. Many SMEs have difficulty returning loans due to the local interest rate, but there are difficulties in the production process due to the price of raw materials derived from imports.

Many factors that affect the achievement of small companies include the influence of internal and external factors (Wang and Wong, 2004).

Success depends on the ability to manage these two factors through the analysis of environmental factors as well as the establishment and implementation of business strategy.

Conducting SMES business when the economy is affected by the Corona Virus is very difficult. Even some sectors of the business are almost paralyzed, affecting the country's economy and causing a slowdown in global economic activity.

With such background, this research to see the influence of consumer behaviour, competitive advantage to SMEs performance so that employers can overcome this problem, and can run some strategies to keep the business running smoothly amid the threat of economic recession due to Corona. 
Due to the emergence of the Corona Virus has an impact on various lifelines, including the activities of businesses, micro, small, and medium enterprises (MSMEs).

\section{LITERATURE REVIEW}

\section{$>$ Consumer behaviour}

According to Schiffman and Kanuk (2004), Consumer behaviour is the process that a person is traversed by seeking, purchasing, using, evaluating, and acting after consumption of products, services, or ideas that are expected to fulfil their needs. Consumer behaviour is the process and activity when a person relates to the search, selection, purchase, use, and evaluation of products and services to meet their needs and desires.

Consumer behaviour is the underpinning of consumers to make purchasing decisions. For valuables selling low-involvement decision-making process is done easily, while for valuables high-selling (high-involvement) decision-making process is done with mature consideration.

\section{$>$ Consumer attitudes}

Attitudes towards a particular brand often affect whether the consumer will then buy or not. A positive attitude towards a specific brand will allow consumers to make purchases against the brand. Some of the variables discussed include:

- Preference, where based (Goulet al, 2000), consumer behaviour in receiving an advertisement in the form of product placement, is influenced by individual differences and also tastes. Watching movies more often is more profitable in accepting product placements, and ethical products are charged. Goulet $\mathrm{Al}$ also argues it can determine the impact after watching a movie. This can be measured from the privileges that the product has, product price, product design to the performance that is owned by a product that can give rise to preference from consumers.

- Intentions to purchase are interest in buying from the interest of the audience to buy products that become product placement in Korean dramas, including those used by the characters in the drama. It can also be seen from a desire to buy products that are consumers of a product. An example case, for example, BMW promoted their new product, the Z3 Roadster, on the GoldenEye by conducting promotions from the company's agents before and after the film was sliced.

Attitudes consist of three main components, namely:

- Cognitive components. Knowledge and perception are gained based on a combination of direct experience with the objects of attitudes and related information from various sources. This knowledge and its perceived perception usually take the form of trust, which is the consumer confidence that the object of attitude has various properties and that certain behaviours will give rise to certain outcomes.
- Affective component. Affective is the consumer's emotions or feelings about a particular product or brand. These emotions and feelings are often considered to have very evaluative properties by consumer researchers, which is to include a person's assessment of the object's attitude directly and thoroughly or to the extent that one assesses an object of fun or unpleasant attitude and is good or ugly.

- Conative components. Conation relates to the possibility or tendency that the individual will perform a special action or behave in a certain way to the object of a particular attitude. The Conative component is often regarded as a consumer intent statement to buy.

A competitive advantage is an advantage over competitors gained by offering consumers at greater value, either with a lower price quote or by providing more benefits to consumer service at a higher price.

While according to the theory of Michael Porter (2013), the sense of competitive advantage is the ability gained through the characteristics and resources of a company to have a higher performance than other companies in the same industry or market. Backed with Hana's theory (2013), the goal of every business is beating competition and winning new customers in a competitive environment.

Back according to Porter (2013), a strategy of competitive advantage that business can do such as being the lowest cost producers in the industry, making different businesses and only a small number on the market or can also rate a premium for the value of additional goods for consumers.

The concept of competitive advantage is developed from the generic strategy that porter put forward (1985). Porter's teachings on generic strategies for competitive advantage consist of cost excellence, differentiation, and customer focus still relevant to stay in use. Competitive advantage is the heart of the company's performance in market competition.

Competitive advantage essentially grows from the value or benefit a company can have for its buyers. If the company is then able to create an edge through one of the three generic strategies submitted by Porter, it will be obtained the competitive advantage (Aaker, 1989). According to Ehmke (2008)

"A Competitive Advantage Is An Advantage Gained Over Competitors By Offering Customer Greater Value, Either Through Lower Prices Or By Providing Additional Benefits And Service That Justify Similarly, or possibly higher prices".

The advantage of competing as a benefit strategy from the company to create more effective competition in its market (Porter, 1993). 
Then lumpkin and dess (2005) stated that a competitive advantage existed when customers felt that the company's products had the advantage of its competitors. Adner and zemsky (2006), a competitive advantage perspective that considers a demand-based perspective. Competitive advantage can be seen from the level of quality importance to the market and classify into 4 (four) resource types in the creation of value, namely, the process of resources to lower the company's cost structure, product resources to improve the company's performance, time resources to deliver value according to market time, and innovation resources to influence technology. According to adner and zemsky (2006), these resources and other resources form the creation of value in the development process of competing superiority of the company.

Business performance becomes the key to stay in the global era and during pandemic covid-19. Many factors that determine the business performance of an organization is to create customers by marketing, innovating, and economic productivity consisting of human resources, capital resources, and physical resources. Some of these factors ultimately improve the business performance of the organization. According to wibowo (2018), performance as a result of work or achievement and how the work process takes place. As for other opinions expressed by amstrong and baron in wibowo (2008), performance is a result of work that has a relationship with strategic objectives of the organization, customer satisfaction, contributing to the economy.

\section{RESEARCH METHOD}

The research was conducted using a methodical approach with quantitative quantitatively. Assessments are conducted to determine the influence and relationship between variables. By emphasizing a quantitative approach, the study demonstrates partial and simultaneous influences between consumer behaviour variables (X1), Competitive advantages (X2), and Performance (Y1). This research uses primary data obtained from questionnaires distributed to 110 SME entrepreneurs in DKI Jakarta. This study uses multiple regression analyses. This analysis is used to measure the strength of two or more variables and also indicate the direction of the relationship between dependent variables and independent variables. Data collected, then processed and also analyzed using SPSS version 16.0.

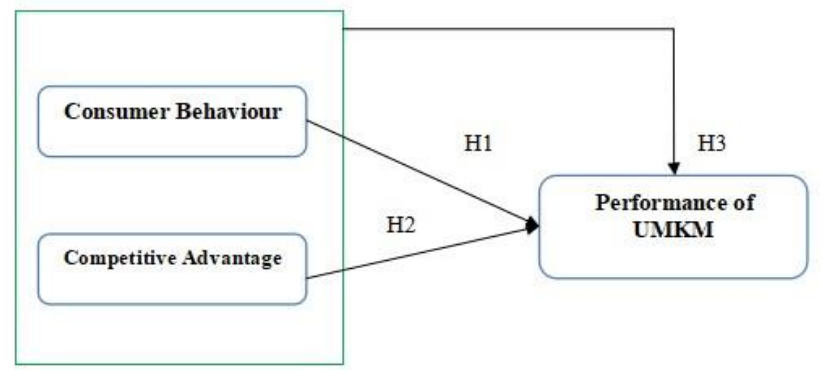

Fig 1:- Framework Model
Hypothesis

H1: Consumer behaviour affects performance

$\mathrm{H} 2$ : Competitive advantage affects performance

H3: Consumer behaviour and competitive advantage affect performance

\section{RESULT AND DISCUSSION}

This research was conducted by spreading the questionnaire to 110 respondents who did business in the area around DKI Jakarta. The results obtained then processed the data using the help of SPSS 16.0 for Windows program, with the following results:

\begin{tabular}{|c|c|c|}
\hline Description & Type & Amount \\
\hline \multirow[t]{2}{*}{ Gender } & Man & 53 \\
\hline & Women & 57 \\
\hline \multirow[t]{4}{*}{ Education } & High School & 26 \\
\hline & Diploma & 2 \\
\hline & Bachelor & 74 \\
\hline & Master & 8 \\
\hline \multirow[t]{5}{*}{ Age } & Less than 20 & 1 \\
\hline & 21 years -30 years & 58 \\
\hline & 31 years -40 years & 30 \\
\hline & 41 years -50 years & 11 \\
\hline & More than 50 years & 10 \\
\hline \multirow[t]{5}{*}{ Revemue (per month) } & $\mathrm{s} / \mathrm{d} \mathrm{Rp} 5.000 .000,00$ & 60 \\
\hline & $\begin{array}{l}\mathrm{Rp} 5.100 .000,00-\mathrm{Rp} \\
10.000 .000,00\end{array}$ & 22 \\
\hline & $\begin{array}{l}\mathrm{Rp} 10.100 .000,00-\mathrm{Rp} \\
15.000 .000,00\end{array}$ & 11 \\
\hline & $\begin{array}{c}\mathrm{Rp}, 15.100 .000,00-\mathrm{Rp} \\
20.000 .000,00\end{array}$ & 7 \\
\hline & More than $\mathrm{Rp} 20.000 .000,00$ & 10 \\
\hline \multirow[t]{4}{*}{ Length of effort } & One year -5 years & 77 \\
\hline & Six years -10 years & 19 \\
\hline & 11 years -15 years & 5 \\
\hline & Above 15 years old & 9 \\
\hline \multirow[t]{4}{*}{ Type of Business } & Food and Beverages & 53 \\
\hline & Services & 23 \\
\hline & Fashion & 18 \\
\hline & Others & 16 \\
\hline
\end{tabular}

Table 1:- Description of Research Objective Source: Data Processing Results 2020

In table 1 , the results of data processing and discussion in this study were obtained from the dissemination of questionnaires to $110 \mathrm{SME}$ actors in the area around DKI Jakarta as primary data. The results of the descriptive analysis showed that respondents were less than 20 as many as one respondents $(0.9 \%)$, aged 21 to 30 years as many as 58 respondents $(52.7 \%), 31$ to 40 years as many as 30 respondents $(27.3 \%), 41$ to 50 as many as 11 respondents $(10 \%)$, and over 50 years as many as ten respondents $(9.1 \%)$. Female Gender 57 respondents $(51.8 \%)$ While the man was 53 respondents $(48.2 \%)$. The last education of high school was 26 respondents $(23.6 \%)$, a 2-Respondent diploma (1.8\%), a Bachelor of $74(67.3 \%)$, and a Master of 8 respondents $(7.3 \%)$. Revenue of Rp. 5,000,000.00, 60 respondents (54.5\%), Rp. 5,100,000.00Rp. $10,000,000.00,22$ respondents (20\%), Rp. 10,100,000.00-Rp. $15,000,000.00$ as much as 11 respondents (10\%), Rp. 15,100,000.00-Rp. 20,000,000.00 as many as seven respondents (6.4\%), and more than Rp. $20,000,000.00$ as much as 10 respondents $(9.1 \%)$. The duration of the effort is 1 year-5 year as many as 77 
respondents (70\%), 6 years-10 years as many as 19 respondents $(17.3 \%), 11$ years-15 years as many as 5 respondents $(4.5 \%)$, over 15 years as many as 9 respondents $(8.2 \%)$. This type of culinary business is 53 (48.2\%), a service of 23 respondents $(20.9 \%)$, fashion as many as 18 respondents $(16.4 \%)$, others as much as $16 \%$ of respondents (14.5\%). The questionnaire consists of 15 question items outlined based on variables to be researched i.e. consumer behaviour (X1), Competitive Advantage (X2) on SME performance (Y).

\begin{tabular}{|l|l|l|l|}
\hline \multicolumn{1}{|c|}{ Variable } & \multicolumn{1}{c|}{$\mathrm{r}$ count } & \multicolumn{1}{c|}{ r table } & \multicolumn{1}{c|}{ Information } \\
\hline $\begin{array}{l}\text { Consumer Behaviour } \\
(\mathrm{X} 1)\end{array}$ & $0.540-0.633$ & 0.1874 & Valid \\
\hline $\begin{array}{l}\text { Competitive } \\
\text { Advantage }(\mathrm{X} 2)\end{array}$ & $0.639-0.854$ & 0.1874 & Valid \\
\hline $\begin{array}{l}\text { Business } \\
\text { Performance (Y) }\end{array}$ & $0.753-0.846$ & 0.1874 & Valid \\
\hline
\end{tabular}

Table 2:- Validity test results on consumer behaviour (X1), Competitive Advantage (X2), and business performance

Based on the table above, it can be seen that with a significant rate of $5 \%$, obtained $r$ table of 0.1874 . In such tables, the validity test for the $\mathrm{X} 1$ variable that is the Varibell of the consumer behaviour indicates all the question items have a value of $\mathrm{R}$ count greater than 0.1874 which means it is valid or feasible to use for research. The validity test for the variable $\mathrm{X} 2$ which is a competitive advantage variable shows all the question items having a value of $R$ count greater than 0.1874 which means it is valid or worthy to be used for research.

The validity test for the $\mathrm{Y}$ variable, which is the consumer behaviour variable shows all the question points has a value of $\mathrm{R}$ count greater than 0.1874 , which means it is valid or worth use for research.

\section{RELIABILITY TEST}

The reliability test is used to demonstrate the level of reliability of the internal consistency by measuring the coefficient of Cronbach's Alpha where variables can be considered reliable when they have an Alpha value greater than 0.60 (Riyanto, 2019). The reliability test results based on Cronbach's Alpha formula can be seen in the table below.

\begin{tabular}{|l|c|c|c|}
\hline \multicolumn{1}{|c|}{ VARIABLE } & $\begin{array}{c}\text { KOEFISIEN } \\
\text { RELIABIITY }\end{array}$ & $\begin{array}{c}\text { CRITICAL } \\
\text { VALUE }\end{array}$ & DESCRIPTION \\
\hline Consumer Behaviour (X1) & 0.617 & 0.6 & RELIABLE \\
\hline Competitive Advantage (X2) & 0.849 & 0.6 & RELIABLE \\
\hline Business Performance (Y) & 0.812 & 0.6 & RELIABLE \\
\hline
\end{tabular}

Table 3:- Reliability test Results

According to the table above, it can be seen that the consumer behaviour variables (X1), the competitive advantage (X2), and the Business performance (Y) have a coefficient value greater than 0.60 with a value each of
0617 for consumer behaviour variables (X1), 0849 for Competitive advantage variables (X2), and 0812 for business performance variables $(\mathrm{Y})$. This indicates that the question item in each variable can be said to be reliable to measure the variability.

\section{Multiple Linear regression equation analysis}

This analysis is used to determine the direction of the relationship between the dependent and independent variables, whether each of them is independent positive or negative, and to predict the value of the dependent variable when there is an increase or decrease in independent variables (Maida, 2017). The results of multiple linear regression analyses can be seen in the table below.

\begin{tabular}{|c|c|c|c|c|c|c|}
\hline \multicolumn{7}{|c|}{ Coefficients } \\
\hline \multirow{2}{*}{\multicolumn{2}{|c|}{ Model }} & \multicolumn{2}{|c|}{ Unstandardized Coefficients } & \multirow{2}{*}{$\begin{array}{c}\begin{array}{c}\text { Standardized } \\
\text { Coefficients }\end{array} \\
\text { Beta }\end{array}$} & \multirow[b]{2}{*}{$\mathrm{t}$} & \multirow[b]{2}{*}{ Sig. } \\
\hline & & B & Std. Error & & & \\
\hline \multirow[t]{3}{*}{1} & (Constant) & 2.150 & 2.279 & & .944 & .348 \\
\hline & Consumer Behaviour & .371 & .111 & .304 & 3.338 & .001 \\
\hline & Competitive Advantage & .182 & .074 & .225 & 2.469 & .015 \\
\hline
\end{tabular}

Table 4:- Multiple Linear regression analysis results

\section{T count $>t$ table $\rightarrow$ no influence. \\ T table: 1.982 \\ (X1 and X2 no influence)}

According to the table above, it can be written into multiple linear regression equations as follows:

$\mathrm{Y}=\mathbf{2 . 1 5 0}+\mathbf{3 . 3 3 8}_{1}+\mathbf{2 . 4 6 9 \mathrm { X } _ { 2 }}$

From the table above, it can be seen that the consumer behaviour variable (X1) obtained the count $\mathrm{T}$ value of 3,338 and the $T$ table of 1,982 . It shows that the $X 1$ variable has a significant effect on the performance of the business as it has a larger count than the T table. Whereas, a variable competitive advantage (X2) obtained a calculated $t$ value of 2,469 and $T$ table of 1,982. This indicates that the variable $\mathrm{X} 2$ has a significant effect on the performance of the business as it has a larger count than table $\mathrm{T}$.

\begin{tabular}{|c|c|c|c|c|c|c|}
\hline \multicolumn{7}{|c|}{ ANOVA } \\
\hline \multicolumn{2}{|c|}{ Model } & $\begin{array}{l}\text { Sum of } \\
\text { Squares }\end{array}$ & df & Mean Square & $\mathrm{F}$ & Sig. \\
\hline \multirow[t]{3}{*}{1} & Regression & 263.084 & 2 & 131.542 & 11.695 & $.000^{3}$ \\
\hline & Residual & 1203.470 & 107 & 11.247 & & \\
\hline & Total & 1466.555 & 109 & & & \\
\hline \multicolumn{6}{|c|}{ a. Predictors: (Constant), Competitive Advantage, Consumer Advantage } & \\
\hline \multicolumn{4}{|c|}{ b. Dependent Variable: Performance Business } & & & \\
\hline
\end{tabular}

Table 5:- Results Uji-F

F count $>$ F table $\rightarrow$ Influence simultaneously

$\mathrm{F}(2 ; 108)=3.08$

$\mathrm{X} 1$ and $\mathrm{X} 2$ Influence simultaneously. 
According to the table above, it is known that the value of $\mathrm{F}$ count has been obtained by 11,695 , where the $\mathrm{F}$ value of the table is 3.08 . This suggests that variables of consumer behaviour and competitive advantage (simultaneous) have a significant effect on the performance of the business because the value of $\mathrm{F}$ count is greater than the $F$ value of the table.

Model Summary

\begin{tabular}{|l|r|r|r|r|}
\hline Model & \multicolumn{1}{|c|}{$\mathrm{R}$} & R Square & \multicolumn{1}{c|}{$\begin{array}{c}\text { Adjusted R } \\
\text { Square }\end{array}$} & $\begin{array}{c}\text { Std. An error } \\
\text { of the Estimate }\end{array}$ \\
\hline 1 & $.524^{\mathrm{a}}$ & .179 & .164 & 3.354 \\
\hline
\end{tabular}

a. Predictors: (Constant), Competitive Advantage, Consumer Advantage

Table 6:- Result coefficient of determination

From the table above can be obtained value coefficient of determination as follows:

$\mathrm{KD}=\mathrm{R} 2 \times 100 \%$

$(0.524) 2 \times 100 \%$

$27 \%$

It shows that consumer behaviour variables (X1) and competitive advantages (X2) provide a simultaneous effect of $27 \%$ on business performance $(\mathrm{Y})$, while the remaining $73 \%$ is influenced by other factors not examined in this study.

\section{CONCLUSION}

Based on the research and analysis of data that has been done, the author gives some conclusions as follows:

$>$ Consumer behaviour positively affects the performance of the business, which is demonstrated between the two variables having a very high relationship. That means better consumer behaviour, then the performance will increase.

> Competitive advantage positively affects the performance of the business, which is demonstrated between the two variables that have a very high relationship. This means that the better the competitive advantage of business performance is increasing.

$>$ Consumer behaviour and competitive advantage positively affect the performance of the business, which is demonstrated between the two variables having a very high relationship. Meaning the better consumer behaviour and competitive advantage, the performance of a business is increasing.

\section{REFERENCES}

[1]. Aaker, D. 1989. Managing Assets and Skills: The Key to a Sustainable Competitive Advantage. California Management Review. Winter: 91-106.

[2]. Adner, R. \& Zemsky, P. 2006. A Demand-based Perspective on Sustainable Competitive Advantage. Strategic Management Journal. Vol. 27. Pp. 215-239.
[3]. Dwiarti, R., \& Wibowo, A. B. (2018). Analisis Pengaruh Tingkat Pendidikan, Kompensasi, dan Lingkungan Kerja Terhadap Kinerja Karyawan pada PT. Taman Wisata Candi Prambanan. Jurnal Perilaku dan Strategi Bisnis (JPSB), 06(02), 157-170.

[4]. Lumpkin, G.T. \& Dess, G.G. 2005. The role of entrepreneurial orientation in stimulating effective corporate entrepreneurship. Academy of Management Executive. 19(1). 147-156.

[5]. Ehmke, C., 2008. Strategies for Competitive Advantage. Paper of Agricultural and Applied Economics Department. Amerika: University of Wyoming.

[6]. Firnanti, Hanna, 2013. Faktor-Faktor Yang Mempengaruhi Kinerja Auditor. Jurnal Bisnis dan Akuntansi. Vol.15.No.1.

[7]. Maida, M.T., Riyanto, S., dan Ali, H. 2017. Effect of Job Satisfaction and Leadership Style Towards Employee Productivity at PT Asuransi Umum Bumiputera Muda 1967. Saudi Journal of Business and Management Studies Vol-2: 157-168.

[8]. Kotler, Philip. Keller Lane, Kevin. 2013. Manajemen Pemasaran, Jilid 1 Edisi 13. Jakarta: PT. Indeks. Prentice Hall.

[9]. Porter, M.E. (1985). Competitive Advantage: Creating and Sustaining Superior Performance: With a new introduction. New York: The Free Press.

[10]. Porter, M.E. (1993). Keunggulan Bersaing: Menciptakan dan Mempertahankan Kinerja Unggul.Jakarta: PT. Gramedia.

[11]. Qolbi, Sahibul, Ummas dan Fauzi, Achmad dan Sunarti.2014.Pengaruh iklan terhadap sikap konsumen (Survei Pada Pengunjung Yang Pernah Bermain Game Pro Evolution Soccer Di Flux Capital of Entertainment Kecamatan Blimbing Kota Malang.

[12]. Riyanto, Setyo. 2019. The Impact of Leadership, Organizational Culture, and Organizational Climate on Employee Job Satisfaction. Advances in Economics, Business, and Management Research vol. 120.

[13]. Schiffman dan Kanuk. 2004. Perilaku Konsumen (edisi 7). Jakarta: Prentice Hall.

[14]. Tandiono, Evy dan Rumambi, Leonid, Julivan S.E.2013. Analisa pengaruh product placement dan brand recall volvo terhadap sikap konsumen dalam film"twilight saga:breaking dawn (part 2)".

[15]. Wang, Clement K., and Wong, Poh-Kam. 2004. Entrepreneurial Interest of University Students in Singapore.

[16]. Wibowo, Amin, 2008, "The Impact Of Organizational Culture And Internal Corporate Governance On Organizational Performance In Indonesian Companies", PhD Curtin University. 